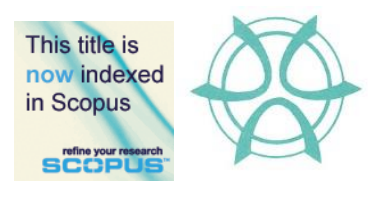

PLANNING MALAYSIA:

Journal of the Malaysian Institute of Planners

VOLUME 15 ISSUE 1 (2017), Page 45 - 56

\title{
THE COMPLEXITY OF GOVERNING FISHING VILLAGES IN THE BAGAN AREAS OF SELANGOR, MALAYSIA
}

\author{
Mohd Zin Mohamed ${ }^{1}$, \& Norhaslina Hassan ${ }^{2}$ \\ ${ }^{I}$ Kulliyyah of Architecture and Environmental Design \\ INTERNATIONAL ISLAMIC UNIVERSITY MALAYSIA \\ ${ }^{2}$ Geography Department \\ UNIVERSITY OF MALAYA
}

\begin{abstract}
This paper examines the current administrative structure that deals with informal fishing villages in Selangor aiming to identify the governance issues of these communities from the local-, district-, state- and federal-level perspectives. Data collection techniques employed were field observations conducted through site visits, in-depth interviews with the state and local planning officials, and focus group discussions involving chairpersons of the Village Development and Security Committees (VDSC). The analysis reveals a sizable number of entities involved in the governance and management of these fishing communities at all levels and accordingly, concludes by outlining a more strategic administrative structure that could effectively govern informal fishing villages that is applicable to Selangor and beyond.
\end{abstract}

Keywords: Village Development and Security Committees (VDSC), administrative structure, fishing villages

Date Received: $30^{\text {th }}$ April 2016

Date of Acceptance: $30^{\text {th }}$ October 2016 
Mohd Zin Mohamed, \& Norhaslina Hassan

The Complexity of Governing Fishing Villages in The Bagan Areas of Selangor, Malaysia

\section{INTRODUCTION}

Many fishing communities in rapidly developing countries are now at a crossroad. Against the backdrop of accelerated urbanization and expanding municipal areas, they are caught between the need to maintain their traditional way of life and embracing development that is increasingly conditioned by sustainable principles leading to uncertainties regarding their future. While the unsustainability of fishing villages has always been attributed to the general lack of infrastructure and public amenities, unplanned settlement and poverty, informal fishing villages are more disadvantaged due to geographical marginalization, basic service deficits, poor governance frameworks, limited access to land and property, precarious livelihoods and, due to their locations in environmentally sensitive areas, high vulnerability to the adverse impacts of poor and exposed environments, climate change and natural disasters. It has indeed been noted that urban sensitive areas in developing countries are currently facing challenges and impacts resulting from processes such as urban sprawl and development, urban agglomeration, tourism development and informal settlements (Trzyna, 2007; Rebelo et al., 2011).

The negative impacts of indiscriminate expansion of informal fishing villages in Malaysia include illegal exploration of land, garbage and sewage problems, socioeconomic problems, lack of road network and improperly installed water and electricity supplies as well as inadequacy of community amenities. Informal fishing villages are more problematic via the traditional ones seen from the development planning perspective. Not only are these villages plagued with environmental and socioeconomic issues, formal planning of these settlements is hindered by the status of land being occupied. This is despite the serious efforts by the government to raise the standard of living for fishing communities, while at the same time improve fisheries conservation and management (Tietze et. al. 2006).

The Department of Local Government has identified 19 new villages in Bagan areas in Selangor covering the districts of Sabak Bernam, Kuala Selangor, Klang, Kuala Langat and Sepang (Figure 1) which do not fall under the categories of the new villages (Brigg's Plan) or "kampung tersusun" (resettlement villages). The Malay word "Bagan" refers to jetty which serves to characterize these villages as settlements with jetties. The location of these fishing villages now is amongst the prime area for development where the majority of the villagers are still without land titles which contributes to their informality status. Effective management of these villages depends to a great extent on the governance structures that are present including their administrative roles, financial support and more importantly, a clear goal on future development of the settlements themselves. Given the informal fishing village's history of marginalization and alienation from policy processes, this paper argues for co-management strategy that can better achieve a more sustainable governance outcomes. It examines the 
PLANNING MALAYSIA

Journal of the Malaysia Institute of Planners (2017)

current administrative structure that deals with informal fishing villages in Selangor aiming to identify the governance issues of these communities and concludes by outlining a more strategic administrative structure that could effectively govern informal fishing villages that is applicable to Selangor and elsewhere.

\section{GOOD GOVERNANCE AND CO-MANAGEMENT}

Governance in the urban management context refers to all of the laws, regulations, frameworks, systems and processes that shape the way in which the local government operates. It is a complex system whose ultimate definition is not only difficult to be claimed by anyone but also highly contextual where the process and practices vary based on the environment in which they are applied. Based on the definition by UNDP, Bello and Dola (2014) have defined local governance as the exercise of economic, political and administrative authority to manage affairs at local levels. Good urban governance provides the legal, political and networking framework in which good management flourishes. A critical element of effective governance at the local government level is the establishment of an inter-governmental institutional framework that (1) clearly specifies the responsibilities of each level of government; (2) provides the appropriate authority to support the delegated responsibilities; (3) specifies and enforces a code of conduct to underpin administration and (4) encourages private sector and civil actors to participate in development or management. Additionally, good governance requires a sound public-private partnership as well as effective government and citizen interaction.

Increasingly, the potential of co-management is seen to provide a strategic governance alternative for a more democratic and participatory decision-making regarding the sustainability of the informal fishing villages within the context of rapidly urbanizing region. Co-management seeks to bring together resource users in shared stakeholder management regimes (Armitage, Berkes \& Doubleday, 2007; Olson, 2009). The premise is that co-management is not just about managing resources but is also fundamentally about managing relationships (Goetze, 2005). By incorporating a diversity of stakeholders, comanagement aims to provide opportunity for building trust and linkages among interested parties. Accordingly, the inclusionary practices are purported to increase the legitimacy of decision-making processes and, furthermore, lead to better resource management by incorporating processes of social learning and knowledge integration (Armitage, Berkes \& Doubleda, 2007; Berkes, 2009). This "co-benefits" by "co-managing" the development process is to be facilitated by strengthening the local administrative machinery in dealing with the complex socio-environmental issues associated with informal fishing villages. Effective co-management demands the creation of an enabling environment that gives power and authority to both government and resource users at community and 
Mohd Zin Mohamed, \& Norhaslina Hassan

The Complexity of Governing Fishing Villages in The Bagan Areas of Selangor, Malaysia

district levels in a broader participatory management process. By-laws at the district authority level should be legally binding and according to which fisheries resources are considered as natural goods for the benefit of the local communities (Njaya, 2007; Olson, 2009).

\section{METHODOLOGY}

Data collection techniques employed in this study were field observations conducted through site visits, in-depth interviews with the state and local planning officials and focus group discussions involving chairpersons of the Village Development and Security Committees (Jawatankuasa Keselamatan dan Kemajuan Kampung - VDSC).

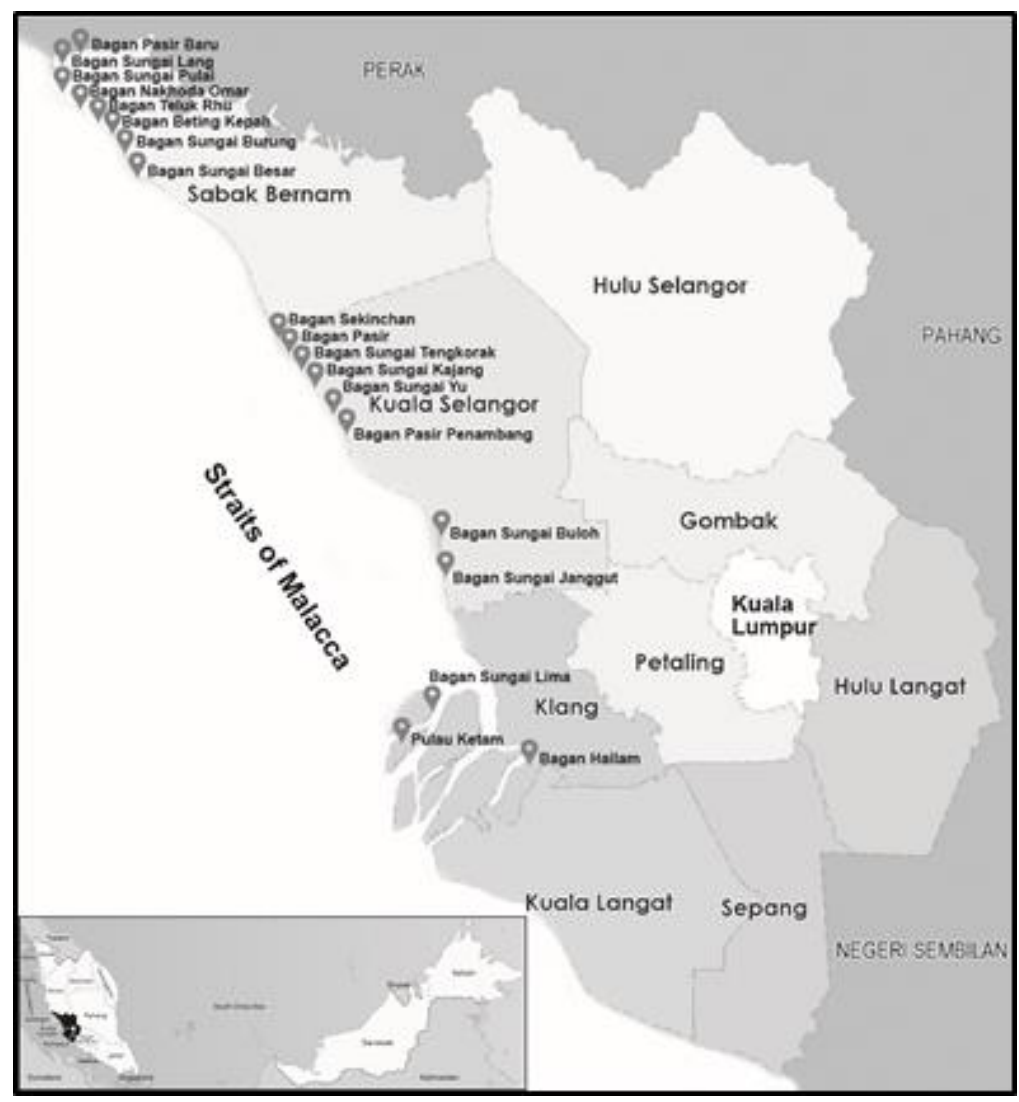

Figure 1 Fishing Villages in the Bagan Areas of Selangor

Quantitative data was collected using questionnaire survey and administered on village residents through purposive and snowball sampling. The survey instrument was distributed among the VDSC committee members who 
PLANNING MALAYSIA

then recruit other respondents from among their acquaintances. This strategy produced a sample of 1,500 head of households; 739 from the villages in the district of Sabak Bernam, 423 from the district of Klang and 328 from the district of Kuala Selangor (from the total of 1,162; 2,240 and 1,194 households in the villages which represent $49.3 \%, 21.9 \%$ and $28.9 \%$ of the total sample respectively. This corresponds to the 5\% sampling error (significance level $(\alpha)$ .05 ) and $95 \%$ level of confidence. The instrument was designed to solicit the general household characteristics, livelihood means and participation in villagebased organisations as communicative channels for community issues at the villagers' level and at the ketua kampung (village heads) level, the 19 Tok Sidang were involved in both FGD sessions and individual semi structured interviews to gather information regarding the flow of information bottom-up and vice versa with higher authorities.

\section{HOUSEHOLD CHARACTERISTICS AND MEMBERSHIP IN VILLAGE-BASED ORGANISATIONS}

The majority (87.5\%) of the respondents surveyed are married and has only primary level education (72.7\%). Although most (67.9\%) head of households reported self-employment there is also a relatively large proportion $(19.5 \%)$ of the surveyed respondents who are either unemployed (due to old age) or retired indicating to the increasing number of aging fishers in the villages. $85.8 \%$ of the households reported having between 1-4 members being involved in the local economy which revolves around the fishing sector. The $14.2 \%$ of the households which did not have any members in the local economic sector shows the trend of increasing disassociation between the fishing villages and the sea as the main source of livelihoods among their current residents.

Almost all (98.3\%) head of households studied said that they own the houses in which they live in. Almost all (90.3\%) head of households rated their housing conditions to be fair. Despite the informality of the fishing villages, the majority of houses were supplied with electricity and water from official utility providers (97.5\% and $97.3 \%$ respectively). However, only $41.6 \%$ of the houses in these villages have modern toilet while the rest drained their domestic sewage directly into the rivers. The study also found that $98.4 \%$ of the head of households surveyed admitted to having stayed in the villages for more than 20 years; $83 \%$ said to have lived there for more than 30 years.

A chi-square test was performed to determine whether the three most common village-based organisations were equally subscribed to by the villagers. The result shows that subscription to the organisations was not equally distributed in the population, $\chi^{2}(4, \mathrm{~N}=1500)=212.4, \mathrm{p}<.05$. Table 1 shows that the villager's resident association was not the preferred organisations compared to the fishermen's cooperation. A large proportion of the respondents also reported non-membership to any organisation in the villages as in the case of the villagers 
Mohd Zin Mohamed, \& Norhaslina Hassan

The Complexity of Governing Fishing Villages in The Bagan Areas of Selangor, Malaysia

in the district of Klang (82.7\%). This however, does not imply community disintegration as communication regarding any issues occurs informally among the villagers given the close-knit structure. The local VDSC which is a small administrative unit that coordinate local level development, nonetheless, still provide the official platform and liaison between the villagers and the government officials on matters pertaining to the villages.

Table 1 Membership in Village-Based Organisations

\begin{tabular}{|c|c|c|c|c|}
\hline \multirow[b]{2}{*}{ Districts } & \multicolumn{3}{|c|}{ Membership in Village-based Organisations } & \multirow[b]{2}{*}{ Total } \\
\hline & $\begin{array}{l}\text { Fishermen } \\
\text { Association/ } \\
\text { Cooperation }\end{array}$ & $\begin{array}{l}\text { Villagers } \\
\text { Association }\end{array}$ & Non Member & \\
\hline \multirow[t]{2}{*}{ Sabak Bernam } & 265 & 122 & 352 & 739 \\
\hline & $35.9 \%$ & $16.5 \%$ & $47.6 \%$ & $100.0 \%$ \\
\hline \multirow[t]{2}{*}{ Klang } & 53 & 22 & 358 & 433 \\
\hline & $12.2 \%$ & $5.1 \%$ & $82.7 \%$ & $100.0 \%$ \\
\hline \multirow[t]{3}{*}{ Kuala Selangor } & 171 & 21 & 136 & 328 \\
\hline & $52.1 \%$ & $6.4 \%$ & $41.5 \%$ & $100.0 \%$ \\
\hline & 489 & 165 & 846 & 1500 \\
\hline Total & $32.6 \%$ & $11.0 \%$ & $56.4 \%$ & $100.0 \%$ \\
\hline
\end{tabular}

GOVERNANCE OF BAGAN FISHING VILLAGES IN SELANGOR

In the context of the state of Selangor, a number of entities play an important role in the management, development and the future growth of the Bagan fishing villages. On a micro-scale, two entities which are the Villages Associations and Fishermen Association/Cooperation are key players in the governance process at the village level (Table 2). While these organizations are non-governmental based organizations, another entity, the Village Development and Security Committee (VDSC) is considered to be an important local government machinery in the governance of a village including that of Bagan fishing villages.

As shown in Figure 2, these VDSCs are under the jurisdiction of respective mukim heads and district offices. In this case study, three district offices play a crucial role in the development of these villages namely the District Offices of Sabak Bernam, Kluang and Klang (Table 2). Matters pertaining to land administration and rural developments are under the ambit of these district offices. By the virtue that all areas under the respective districts are also the gazetted areas of local governments, local authorities do play significant roles in the welfare of these fishing communities in terms of urban services delivery such as garbage collection and disposal as well as provision of other public amenities. 
PLANNING MALAYSIA

Journal of the Malaysia Institute of Planners (2017)

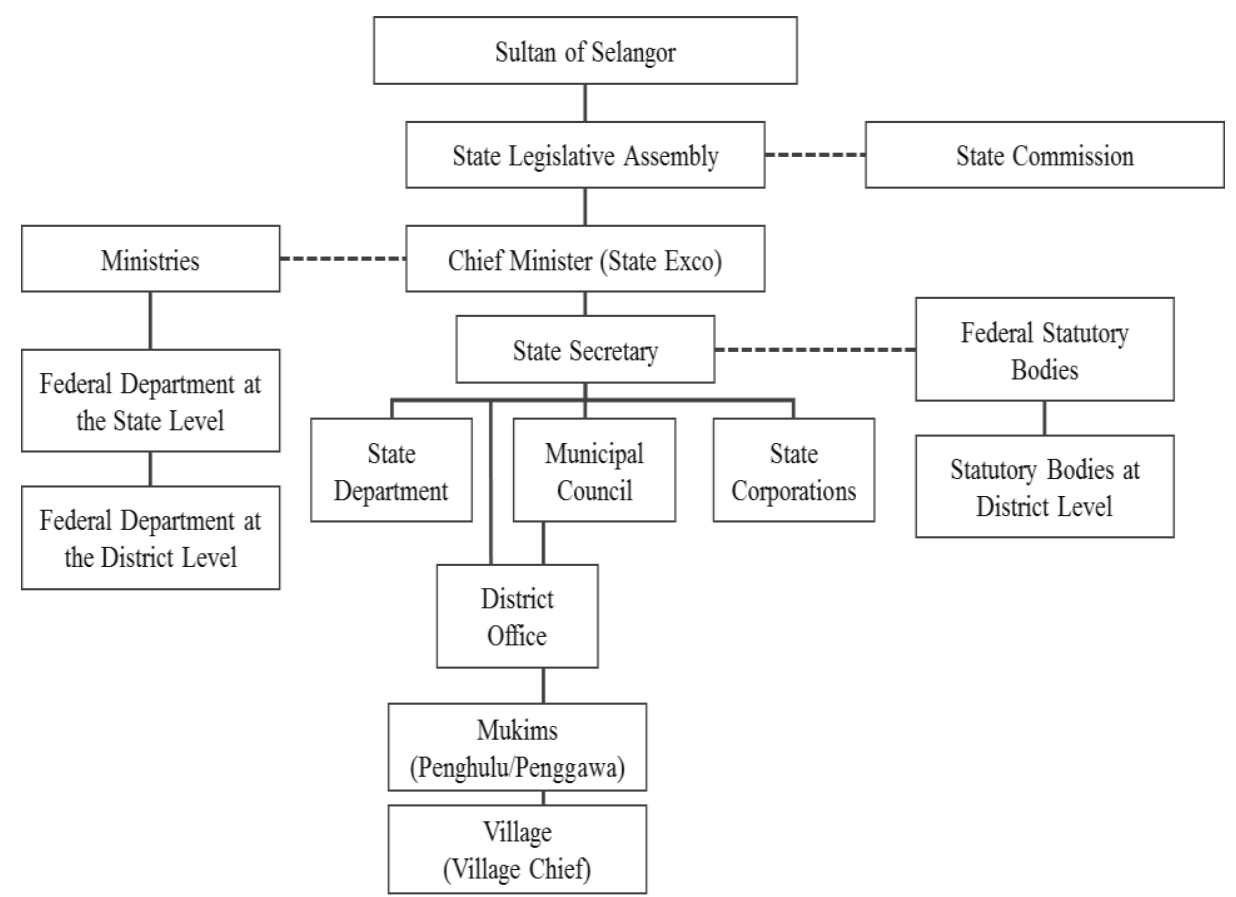

Figure 2 Administrative Structure of the State of Selangor Source: Official Portal of Selangor State Government (www.selangor.gov.my)

Further up the state administrative structure, other government entities also pay important contributions in terms of its public policy decision and implementation of development programmes. The State Economic Planning Unit (SEPU) for example, is responsible for the planning and future development of these villages whilst the State Town and Country Planning Department (STCPD) involves in the physical planning of these villages. Another state entity, the State Land and Mines Department (SLMD) is responsible for land matters of the fishing communities. However, in the state structure the ultimate decision with regards to the development of these fishing villages and their future direction of growth lies with the State Executive Committee (EXCO) or sometimes referred to as the State Cabinet which is chaired by the Chief Minister of Selangor. Under this EXCO system, there are a number of committees established of which a committee called Committee of Investment, Industries, Commerce, New Villages and Illegal Factories chaired by a state assemblyman is responsible for matters in relation to Bagan fishing villages in Selangor.

Based on the FGD among selected villages and VDSC members in the three districts, a number of observations/findings can be made related to the issues of governance in these fishing villages of which two concerns are most prominent as follows: 
Mohd Zin Mohamed, \& Norhaslina Hassan

The Complexity of Governing Fishing Villages in The Bagan Areas of Selangor, Malaysia

i. One of the important governance issues gravitated around the status of the land of the village the fishers are residing which is on 'temporary occupation license (TOL)' status. The majority of the residents prefer to continue staying in these villages to earn their livelihood that they have sustained for at least two generations. Their economic livelihood centres on the need to improve their economic status particularly those related to fishing activities.

ii. Given the uncertainty with the status of ownership, it remains one of the challenges of VDSC to find a solution to this issue. It is felt that the award of permanent titles to the land will provide them with the confidence to make investments such as upgrading their place of residence, participation in tourism projects and fishing sector.

Given the rapidly urbanizing scenario in Selangor, it is a matter of time that these fishing villages will be engulfed by the wind of urban change. This brings into question the survival and sustainability of theses villages. One of the strategic approach in adapting these fishing communities would be through a system of co-management that encourages local public participation, inclusionary practices as well as strengthening local machinery to address various governance issues for the betterment and welfare of the fishing communities (Armitage, Berkes \& Doubleday, 2007; Olson, 2009).

In the case of Bagan fishing villages, the first strategic step would be to strengthen the VDSC by beefing up its capacity and capability through enhancement of expertise, skill and knowledge in order to provide a good service to its communities. In such a case, the role of the District Offices of Sabak Bernam, Kuala Selangor and Klang together with the local authorities of Sabak Bernam District Council, Kuala Selangor District Council and Klang Municipal Council are to assume a leadership role in enhancing the effectiveness of the local machinery (VDSC). On a slightly broader scale of governance, the state and local agencies that have bearing on the development of fishing villages and communities either in the form of policy formulation, coordination of development programmes, project implementation, enforcement of regulations or monitoring of projects are provided in Table 2.

Table 2 Federal and State Agencies Involved in the Management and Implementation of Development Projects at Fishing Village Level

\begin{tabular}{|l|l|l|l|l|l|}
\hline Agencies & Formulation & Coordination & $\begin{array}{c}\text { Implementati } \\
\text { on }\end{array}$ & $\begin{array}{c}\text { Enforcement } \\
\text { Monitoring }\end{array}$ \\
\hline STCP & $\sqrt{ }$ & $\sqrt{ }$ & $\sqrt{ }$ & & $\sqrt{ }$ \\
\hline SEPU & $\sqrt{ }$ & $\sqrt{ }$ & $\sqrt{ }$ & & $\sqrt{ }$ \\
\hline DID & $\sqrt{ }$ & $\sqrt{ }$ & $\sqrt{ }$ & & $\sqrt{ }$ \\
\hline PWD & $\sqrt{ }$ & $\sqrt{ }$ & $\sqrt{ }$ & $\sqrt{ }$ \\
\hline
\end{tabular}


PLANNING MALAYSIA

Journal of the Malaysia Institute of Planners (2017)

\begin{tabular}{|l|l|l|l|l|l|}
\hline JPNS & $\sqrt{ }$ & & $\sqrt{ }$ & $\sqrt{ }$ & $\sqrt{ }$ \\
\hline DWNP & $\sqrt{ }$ & $\sqrt{ }$ & $\sqrt{ }$ & $\sqrt{ }$ & $\sqrt{ }$ \\
\hline CDD & $\sqrt{ }$ & & $\sqrt{ }$ & & \\
\hline JKOA & $\sqrt{ }$ & & $\sqrt{ }$ & & $\sqrt{ }$ \\
\hline BOMBA & $\sqrt{ }$ & & $\sqrt{ }$ & & $\sqrt{ }$ \\
\hline POLICE & $\sqrt{ }$ & & $\sqrt{ }$ & & $\sqrt{ }$ \\
\hline JKKS & $\sqrt{ }$ & & $\sqrt{ }$ & & $\sqrt{ }$ \\
\hline DOE & $\sqrt{ }$ & & $\sqrt{ }$ & $\sqrt{ }$ & $\sqrt{ }$ \\
\hline SWMA & $\sqrt{ }$ & & $\sqrt{ }$ & $\sqrt{ }$ & $\sqrt{ }$ \\
\hline LKIM & $\sqrt{ }$ & & $\sqrt{ }$ & $\sqrt{ }$ & $\sqrt{ }$ \\
\hline TSB & $\sqrt{ }$ & & $\sqrt{ }$ & $\sqrt{ }$ & $\sqrt{ }$ \\
\hline LA & $\sqrt{ }$ & $\sqrt{ }$ & $\sqrt{ }$ & $\sqrt{ }$ & $\sqrt{ }$ \\
\hline LDO & $\sqrt{ }$ & $\sqrt{ }$ & $\sqrt{ }$ & $\sqrt{ }$ \\
\hline
\end{tabular}

\section{IMPLICATIONS OF THE STUDY}

The study on the fishing communities in the three districts of Selangor, namely, the District of Sabak Bernam, Klang and Kuala Selangor unravels the complexity of local governance against the backdrop of the rapidly urbanizing state of Selangor. The future or survival of these 19 villages or communities hinges, to a larger extent, on how these entities adjust and adapt to the ever-changing socioeconomic and political environment in order to stay functional and relevant. Failure to strategize will lead these villages to lose their traditional way of living and hence its heritage importance. To survive, it entails a skilful and strategic governance approach to navigate among the diversity of stakeholders, optimizing the availability of human as well as financial resources and in line with the developmental objectives and need of a developed state like Selangor (Goetze, 2005). This study underlines the need to have a strong and effective local administrative structure in the form of the Village Development and Security Committee established within the state administrative machinery to play the role of promoter and facilitator of socio-economic development at the village level. To this, it calls for VDSC to adopt a co-management strategy, not only to manage resources but also managing relationships among the stakeholders to ensure the orderly growth of these fishing villages into modern entities and yet retaining their traditional characters and become important heritage of Selangor. The study also underpins the importance of building capacity and capability of these VDSC to meet the challenges of local governance in an urban setting.

\section{CONCLUSION}

This paper clearly shows the complexity of governance of Bagan fishing villages in the State of Selangor as shown by the presence of many stakeholders at the state and local levels. The analysis reveals that the administrative structure at the district level is most effective in managing development issues of informal fishing 
Mohd Zin Mohamed, \& Norhaslina Hassan

The Complexity of Governing Fishing Villages in The Bagan Areas of Selangor, Malaysia

villages in Selangor. The VDSC together with the Office of Village Communication Officer at the District Land Office, however, need to be strengthened as they are important entities that effectively bridge the gap between local and state level development planning. This complexity of governance underpins the importance of adopting co-management strategy as a strategic governance alternative to ensure the survival of these fishing villages in the Bagan areas within the context of rapidly urbanizing State of Selangor.

\begin{tabular}{|c|c|c|c|}
\hline \multicolumn{4}{|c|}{ ABBREVIATION } \\
\hline VDSC & Village Development \& Security Committee & CDD & $\begin{array}{l}\text { Selangor } \\
\text { Department }\end{array}$ \\
\hline $\mathrm{ECXO}$ & State Executive Committee & JAKOA & Department of Orang Asli Development \\
\hline STCPD & State Town \& Country Planning Department & BOMBA & $\begin{array}{l}\text { Selangor Fire \& Rescue Department of } \\
\text { Malaysia }\end{array}$ \\
\hline SLMD & State Land \& Mines Department & POLICE & Selangor Royal Malaysia Police \\
\hline SEPU & State Economic Planning Unit & JKKS & Selangor Department of Health \\
\hline DID & Department of Irrigation \& Drainage & DOE & Department of Environment \\
\hline PWD & Public Works Department & SWMA & Selangor Waters Management Authority \\
\hline LDO & Land District Office & LKIM & Fisheries Development Authority of Malaysia \\
\hline JPNS & Selangor Education Department & TSB & Tourism Selangor Berhad \\
\hline DWNP & Department of Wildlife \& National Parks & LA & Local Authority \\
\hline
\end{tabular}

\section{REFERENCES}

Armitage, D., Berkes, F., \& Doubleday, N. (Eds). (2007). Adaptive co-management: collaboration, learning and multi-level governance. Vancouver: University of British Columbia Press.

Bello, A., \& Dola, K. (2014). Sustainable development and the role of local governance : experience from Malaysian model regions. International Journal of Humanities and Social Science, 4(1), 268-280.

Berkes, F. (2009). Evolution of co-management: role of knowledge generation, bridging organisations and social learning. Journal of Environmental Management, 90, 1692-1702.

Goetze, T.C. (2005). Empowered co-management: towards power-sharing and indigenous rights in Clayoquot Sound, BC. Anthropologica, 47(2), 247-265.

Njaya, F. (2007). Governance challenges for the implementation of fisheries comanagement : experiences from Malawi. International Journal of the Commons, $1(1), 137-153$.

Olson, M. (2009). The logic of collective action: public goods and the theory of groups (Vol. 124), Cambridge: Harvard University Press.

Rebelo, A.G., Holmes, P.M., Dorse, C. \& Wood, J. (2011). Impacts of urbanization in a biodiversity hotspot: conservation challenges in Metropolitan Cape Town, South Africa. Journal of Botany, 77 (1), 20-35.

Tietze, U., Haughton, M., \& Siar, S.V. (Eds), (2006). Socio-economic indicators in integrated coastal zone and community-based fisheries management - case studies from the Caribbean. FAO Fisheries Technical Paper (491). Rome: FAO.

Trzyna, T. (2007). Global urbanization and protected areas. California: California Institute of Public Affairs. 